\title{
The National and University Library in Ljubljana - the intersection of Time and Cultures
}

by MARKO MUŠIČ

The slides of this paper can be found at: http://www.zhbluzern.ch/LIBERLAG/PP_LAG_04/Thursday/M_Music/presentation_Music_Marko_UKL.pdf

\section{INTRODUCTION}

As any important architectural work, the libraries from the distant past are vivid organisms that bear in themselves the biological, historical and humanistic experience. Those who live with, and use, such architecture feel its spiritual energy and its vital palpitation. The space accepts them and through symbols and rituals it passes on their idea; it passes on the situation today, however, this is performed from its yesterday's and tomorrow's position. Therefore, good library architecture does not follow changes in trends and fashion, but lives its own time in the continuum of historical consciousness, revealing the spirit and importance of its existence. In the architectural Renaissance taking place during the last years libraries became exactly the same as the important buildings throughout history used to be. They are prestigious architectural achievements that became the visual and symbolic signs of national pride, the cathedrals of our days.

It is impossible to determine why the new libraries (as for example "the Black Diamond", the new annex of the Danish Royal Library, the National Library in Paris, the University Library in Göttingen or the new Biblioteca Alexandrina) appear as they do simply with the statement that such as they are they optimally fulfil the aims and visions of librarians. They most certainly do. However, the reason for being as they are (and as so many other recent libraries in the world) lies in the meaning and mission of architecture as symbolic art.

Already from the ancient times onwards the importance of libraries is determined by the mysterious intertwining of documentation, information and knowledge as well as the symbolic and ritual meanings. The importance of libraries in Antiquity is clearly illustrated by the ritual path to the highest level of the forum of Traian, to the temple of Divi Traiani, that in its last part led between the Greek and the Latin Library. In the evolution of European architecture it is impossible to avoid the fact that designing libraries was consequently attributed to the best architects who were able to give them also the necessary rituality that does accompany our spiritual and physical existence on the other side of religion. From Michelangello and his Medicean Library, Laurentiana, Domenico Fontana and his Vatican Library, Balthasar Longhena and Jacoppo Sansovino and their well known Venetian libraries to the baroque genius Francesco Borromini who created with his Biblioteca Vallicelliana also the first public library of the eternal city, the list of outstanding architects and clients lead through the $18^{\text {th }}$ and $19^{\text {th }}$ century (that are well presented with the Royal Library in Vienna by Johan and his son Emanuel Fischer von Erlach and the Reading hall in the Paris National Library by Henry Labrouste) right to the $20^{\text {th }}$ century that was especially important for the development of the architecture and its position in the contemporary world with many important architects of library buildings (from which we should give a mention at least to the humanistic opus of Alvar Aalto).

\section{THE NATIONAL AND UNIVERSITY LIBRARY OF JOŽE PLEČNIK}

This is the noble tradition to which the National and University Library in Ljubljana (NUK) by the famous Slovenian architect Jože Plečnik should be attached. This library is certainly his best work in his homeland and probably also the best of all the works of this architectural genius who worked in Vienna (let us remind you at least of his Zacherl house) in Prague (where he renewed the Hradčani castle for the president Masaryk) and Ljubljana, the town of his birth and death. Today every educated and ambitious architect in the world is acquainted with Jože Plečnik and his works, which belong in the architectural treasury of the $20^{\text {th }}$ century. It is therefore my privilege to touch his wonderful library with some of the most impressive architectural motives. These are the great staircase and the colonnade of the $1^{\text {st }}$ floor perystil, the famous symbolical path from the banality, rumour and rush of the every day life to the consecrated silence of the spiritual, from the darkness of ignorance to the brightness of knowledge and erudition that is revealed in the great reading room. Another mighty experience is the exterior of the palace conceived with the idea of wrapped textile and the high columns with the bronze capitals that rise in front of the large reading room. The National and University Library by Jože Plečnik was built 
in unpleasant times just before the Second World War, in 1941, and was damaged in 1944 due to a fall of a military airplane. After the war the building was repaired. During the decades following the war, while the Ljubljana University and national functions flourished, the palace soon became too small and overcrowded with library materials and visitors. The bad conditions of work and study and the insufficiency of the magazine section dictated the new building that is unfortunately still not realised.

\section{THE NEW NATIONAL AND UNIVERSITY LIBRARY}

The new National and University Library (UKL) is in close vicinity to the Plečnik's palace. It is inserted in the settlement continuity of our town and into its most beautiful and most precious part, which was in particularly marked by the architect Jože Plečnik and his numerous interventions. The chosen position links the new library directly to the heart of our country and its capital, to the condensed area of the most important cultural institutions and the core of the university heartbeat. With the revival of the memory of the Roman settlement of Aemona and the inclusion of the archaeological heritage into the building of the new library and its direct surroundings the project obtained a new, higher dimension. Henceforth the new library is a cross-point of three periods and cultures. Through the present the past is seeking for the future; the civilised antique period flows into our Slovene culture and the world cultures, which can be found in the numerous publications kept in the library.

The presence of the two Roman streets that define the ground floor level in the new library, the town parterre, overcomes the traditional idea of the building, filling it with urban design dimension. Both streets of the Roman town and parts of houses, the insulas which are included into the new library are at the same time the testimony of the presence and characteristics of the Roman settlement and the linkages and spatial motives that give to the large, open areas of the new library clearly distinguished, environmentally strong and symbolically rich frames of experience structure. The culture of Antiquity is not merely a passive part of a museological display but a vital, active and even central area of the most frequented levels, programmes and spaces. The presence of the Roman town is evident on the three most important levels: in the urban design dimension of the Roman streets and built islands, insulas, in some selected, most important and entirely presented architectural motives and in a large number of different archaeological remains and pieces of art that in various ways enrich the public areas of the new library.

The archaeological memory of the Roman settlement and the new library interweave one with another, with the recent settling layers presented in the existing buildings included in the new library and its surroundings. The historical presence plays an important part in the new spaces and their meaning. The presence of the past is used as a catalyst in order to make the areas and atmospheres in the new building clearer, better expressed and more precious. In this context the hierarchy of the main, connecting areas, largest and most frequented areas as well as the numerous, through milieu and atmosphere heterogeneous study and working areas is especially clear.

The interior of the building reflects the search for a clear relation between those elements; arrangements and environments that constitute the basic structure and all other 'neutral' areas that must (according to the meaning and needs of a contemporary library or information centre) remain open, flexible and always adaptable to the challenges and needs of the future. The main quality of the vast interiors is the presence of the leading themes that as 'Leitmotifs' in a musical composition represent the basic structure, the sovereign support and connection of neutral and flexible, adaptable and ever changing arrangements of spaces.

The project is thus a search for the balance between the interior of the building, which has to enable the best possible conditions for performing the numerous and demanding activities of the new library and the building exterior, which respectfully and sensitively as well as recognisably and self-confidently places the new building into the most precious areas of historic, cultural and artistic memory of our town. Amongst all art, architecture is the form that has always been given the role of the durable and most sincere message of the period and society that constructed it. And this is the lineage that we have followed with our project from the very beginning. Instead of the fugacity of the current directions and the constantly changing fashionable moments, the strong point of this project can be found in the search for qualities, which are durable and which in the search and revival of wisdom and encouragement from the past surpass the present and are becoming the bright constants of the future. 


\section{Ground floor (0 level)}

As in any public building this is the level of programme and communication links with the town. In this building the exciting space of the surrounding streets is enriched by various public spaces and activities that are opened to the town. The largest between them are the entrance vestibule, the inner court for multipurpose activities, the auditorium and the exposition gallery with the permanent presentation of the rich history of this part of the town, the work of Jože Plečnik and with an open space for various temporary exhibitions. The periphery of the ground floor continues with various public programmes such as the library bookshop, the 24-hour library, the German reading centre, the information and documentation centre of the European Council, etc. In the most beautiful and most frequented corner area a cafeteria and art gallery that also define the southern entrance to the library enrich these programmes.

The main entrance is close to the Plečnik's library. The view of his ecstatic architectural masterpiece enters deep into the interior of the new library through a large and curved glass wall, which is oriented towards NUK. The main entrance axis leads through the entire building connecting the entrance vestibule, the nucleus of public activities, with the internal part of the library, the central communication area and the large information centre. Between the external and internal part one can find the information and lending facilities as well as the textbook lending section.

The ground floor of this building is strongly marked with the memory of the Roman town. There are two Roman streets that enter the ground floor of the new library. Through inversion the antiquity remains reveal the urban design culture of antiquity within the interior of a contemporary building. The Roman streets and fragments of the four insulas, the built islands between the streets, enter into the interior of the building through the continuity of their out-door presentation. The town-planning dimension of the Roman Aemona is enriched with carefully prepared presentations of the most important and interesting architectural motifs, several impluviums, Roman inner courts with collonades and halls with mosaics. The streets of the Roman town are displayed in the vast area of the newspaper section that continues into an even larger and with archaeological themes enriched area in the first basement floor. Beside the several entirely reconstructed motives of Roman architecture a special architectural challenge is represented by the two level area of the newspaper reading room fully arranged within the street space of the Roman town. The crossing of the Roman streets is symbolically fulfilled with the main communication core of the new building.

Through the attractive public programmes and the archaeological atmosphere of the inner and outer space the ground floor of the new library is fully incorporated into the historical centre of the town, into the university area and into the beautiful environment of Plečnik's Ljubljana. The library itself is also located in the close vicinity of the representational and administrative centre of Slovenia.

\section{The mezzanine of the ground floor (the $0 \mathrm{M}$ level)}

This level is characterised by the sector that gives the main entrance space on the ground floor, i.e. the vestibule, auditorium and the additional height of the information centre. In the northern corner lies the cafeteria for the inner visitors of the library. The cafeteria is enriched with a panoramic café and restaurant for the numerous visitors of this beautiful part of the town. The main area of this level is the periodical section (NUK). The materials are in free access with individual and collective reading and study areas. This section is rounded up with the centre for business information and the referral centre. The main architectural attractions of this level are the two corner panoramic terraces and elevations that open to the superb panorama of the town immediately above the ruins of the Roman town. The science and information section in the western wing is close to the most important library programmes and in the close vicinity of the Faculty of Arts, where it belongs.

\section{First floor (the +1 level)}

This is the largest level with the main central area measuring $60 x 60$ meters with two narrow wings that are connected to the existing buildings. This is the level of the Central Technological Library of the Ljubljana University (CTK). This important and through decades independent library shall preserve its present organisation also in the new library building. This means that it will preserve the entire monographic and periodical material as well as complete autonomy (at least during the first period). Adjacent to the free access area in the main bloc one can find the accompanying programmes. In the northern wing this incorporates also the existing houses in the vicinity of Plečnik's library that represent a large auditorium/lecture room, an exposition gallery and the club of technical intelligence. In the western wing this also includes one of the existing buildings in which the internal services together with the department for purchasing and treating of materials and the CTK management are located. The two large terraces with a superb view of the old town represent the 
outstanding value and architectural attraction of this level. Glass roofs that bring sufficient daylight into the interior enrich the inner space of public areas.

\section{The mezzanine of the first floor (the $+1 \mathrm{M}$ level)}

This is the level that opens into the vast and high space under the glass roof. The level is far enough from the elevations to preserve the natural lighting of the lower, first floor level. This is the level of monographs (NUK). The free access area is located around the central communication core, while the reading and study spaces are located around the panoramic balconies on both external sides towards the streets and in the gulfs of the inner side, the pleasant environment by the courtyard where the building is also covered with a glass roof. The visitors' spaces are additionally enriched by the smaller study rooms in the corner rotunda, the accentuated architectural motive, and the memory of the medieval tower on this location that was unfortunately demolished immediately after the Second World War. Similar to the lower level and the Central Technological Library, the monograph section (NUK) is also rounded up with lecture rooms, an exhibition space and a cafeteria. In the narrower wing that connects one of the existing buildings there are internal programmes including purchasing and treating all materials not included in the CTK department.

\section{The second floor (the +2 level)}

According to the increasing distance from the visual space of the streets the upper part of the building is much smaller and removed into the depth of the building (quadrangle). The diminution of floor surface offers the possibility of large glass roofs for excellent daylight in the lower levels. This level increases the monograph section (NUK) of the first floor mezzanine. In the narrow wing, that connects one of the existing and renewed buildings, the State centre for research and development and the State library centre are located. In the high (in relation to the existing roofs) roof above this level of the new building the machine rooms for air conditioning, etc. are located. From the basic volume of the new building that is carefully co-ordinated with the existing houses, peaks only the architectural accent in the form of the corner rotunda, marking the already mentioned unfortunately demolished medieval tower on the very same location. Alongside the wall of the rotunda are small study cells, carrels that are arranged in several levels. The main part of the rotunda interior is empty, thus providing natural light that enters through the glass roof of the rotunda to the lower levels.

\section{First basement floor (the -1 level)}

Together with the ground floor this level is abundantly marked with preserved and reconstructed motives of the Roman town Aemona. There is a well-preserved part of a Roman street that (in the northern part of the new building) flows into Decumanus, the main cross communication of the Roman town-planning. In the part of the street that remains presented and reconstructed with all elements is a parlatorium, the ambience of entrance and meeting programmes and different events. Additional attraction of the parlatorium lies in its openness towards the inner court, the future lapidarium in situ. There are several other entrance programmes linked to the parlatorium, such as the student bookshop, the cyber café, public cloakrooms and sanitary facilities.

The promenade, the inner street that extends the public programmes from the ground floor to the basement level leads from the entrance area and parlatorium towards the southern part of the presented Roman remains. This promenade connects the AV centre, the two computer study rooms and the AV auditorium. On the southern side the promenade ends in the area of rich Roman presence partly presented in situ. The "Student Cellar", a traditional pub of the old Ljubljana University ends our promenade and connects it to its ground floor continuation.

On the western side there is another area with a rich presentation of the Roman culture within the new building. This is the area of the newspaper collection (NUK). The ambience of the Roman street that is presented in two levels of the new building is rearranged into the already mentioned reading room that opens into the inner court, the lapidarium in situ. The most outstanding motives of antiquity are completely reconstructed and presented in insula XIII, which is partially incorporated into the new building and includes the two impluviums and the mosaic hall.

The internal part in the centre of this level is connected to the delivery of library material and official and handicapped parking. The offices of the library material purchase and processing department are opened into the inner court, the lapidarium in situ that shall be arranged on the original level of the early Aemona, which is close to the level of the basement floor. The lapidarium in the inner court is therefore an attractive outdoor enrichment for the visitors of the new library. The covered peripheral promenade of the lapidarium is at the same time also a shelter, for it offers protection for the most important artefacts and the panoramic gallery of the public communications on the ground floor level. 
Second, third and the fourth basement floors (the $-2,-3$ and -4 levels)

The three basements are the areas of library material storage. Storage areas are partially classical (the eastern side of the building) and automated high-bay warehouses (in the main and on the southern side of the basements). In the proximity of the central communication area of the second basement there are several services, such as the university printing office and desktop publishing, microfilm lab, the computer centre and workshops for building maintenance. A quite large area of the third and fourth basement floor is reserved for various machine rooms.

At the end of this presentation we must ask ourselves what shall happen to the famous library by Jože Plečnik after the construction of the new building. The architectural masterpiece shall be discharged of many activities that were never planned in it and that shall be (together with the crowd of students, visitors and library materials) removed into the new building. In the palace only the most important and most precious collections shall remain, such as the collection of manuscripts, the musical collection, the graphic and maps collection and the collection of nationally most important documents. In the representative southern wing a permanent exposition of the Slovenian Book shall be organised. It is only then that the palace shall be reined by the solemn atmosphere that Jože Plečnik had in mind while designing this temple of his nation's culture.

\section{APPENDIX - LOCATION \& SOME FIGURES}

\section{Location}

Ljubljana, Slovenija. The new building ( $\underline{\mathrm{UKL}})$ is in vicinity of the National and University Library of Jože Plečnik (NUK). It is in the inner centre of Ljubljana, in the centre of Ljubljana University, in the centre of of the main cultural and scientific institutions and in the core of the historic town.

\section{Architect}

Marko Mušič, univ. dipl., ing., arch.; member of the Slovenian Academy of Sciences and Arts (SAZU).

\section{Total floor area: $37.075 \mathrm{~m}^{2}$}

- $\quad$ Areas for users (library materials in free access, reading and study areas etc.), $15.430 \mathrm{~m}^{2}(42 \%)$

- Closed access stacks and additional programmes, $7.779 \mathrm{~m}^{2}(21 \%)$

- $\quad$ The science and information department, $1.164 \mathrm{~m}^{2}(3 \%)$

- $\quad$ Lecture rooms and auditoriums, $2.297 \mathrm{~m}^{2}(6 \%)$

- Administration and staff area, $4.081 \mathrm{~m}^{2}(11 \%)$

- Additional public programmes (Art Gallery, the German reading center, the Information and documentation centre of the European Council, public refreshments etc.), $2.181 \mathrm{~m}^{2}(6 \%)$

- Mechanical features and other technical areas, $4.143 \mathrm{~m}^{2}(11 \%)$

Total number of reader seats: 850

- Computers: 201

- Audiovisual: 95

- $\quad$ Read and study: 478

- Carrels: 56

- Other (visually handicapped visitors): 20

Total number of seats in auditoriums and lecture rooms: 660 
- Auditorium: 360 seats

- Lecture room 1: 125 seats

- Lecture room 2: 68 seats

- Multimedia lecture room: 52 seats

- Computer lecture room 1: 30 seats

- Computer lecture room 2: 25 seats

Total capacity of shelving: $3,101.000$ volumes

Newspapers: 56.000 (total), open access: 12.000 , closed access: 44.000

Audiovisual material: 112.000 (total), open access: 7.000, closed access: 112.000

Periodicals: 331.000 (total), open access: 31.000, closed access (automated high-bay warehouse): 300.000

Monographs: 2,602.000 (total), open access: 235.000, closed access: 967.000, closed access (automated high-bay warehouse): $1,400.000$

\section{WEB SITES REFERRED TO IN THE TEXT}

Jože Plečnik. http://www.ijs.si/slo/ljubljana/plecnik.html

National and University Library (NUK). http://www.ijs.si/slo/ljubljana/library.html

Ljubljana University Library building (UKL). http://www.nuk.uni-lj.si/eng/new building.html 